\title{
Retóricas de uma fé racional: superação e desejo na religião do consumo
}

\author{
Rethorics on a rational faith: overcoming and desire in the religion of \\ consumption \\ Retórica de una fe racional: resiliencia y el deseoenreligión del consumo \\ Karla Patriota Bronsztein ${ }^{1}$ \\ Carolina Cavalcanti Falcão ${ }^{2}$ \\ Emanuelle Gonçalves Rodrigues ${ }^{3}$
}

\section{Resumo}

Este trabalho parte da perspectiva de instauração de duas retóricas (da "superação" e do "desejo") como alicerce estrutural do que chamamos aqui de Religião do Consumo. A primeira tem expressão no discurso de conquista da Igreja Universal do Reino de Deus - IURD, materializado principalmente na posse de bens materiais - representação máxima da felicidade e prova da ação de Deus sobre a vida do fiel. A segunda se constrói discursivamente em processos que visam a sua própria moralização, praticamente transformando-o numa "obrigação moral". Nossa proposta é refletir sobre o modo como as religiões contemporâneas estão cada vez mais afinadas com o consumo moderno, considerando a total dependência dos testemunhos midiáticos dos fiéis para a promoção de um modo singular de vivência religiosa. Para tanto, analisamos alguns testemunhos de fiéis da IURDdisponíveis no Youtube.

Palavras-chave: Religião do consumo. Retórica da superação. Retórica do desejo. Igreja Universal do Reino de Deus.

\begin{abstract} available on Youtube.

\begin{tabular}{|c|c|}
\hline \multicolumn{2}{|r|}{ Acesse este artigo online } \\
\hline QR CODE: & $\begin{array}{l}\text { Website: } \\
\text { http://www.revistas.ufg.br/index.php/ci }\end{array}$ \\
\hline 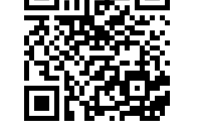 & $\begin{array}{l}\text { DOI: } \\
\text { http://dx.doi.org/10.5216/c\&i.v19i1.358 } \\
59\end{array}$ \\
\hline
\end{tabular}
\end{abstract}

This paper establishes two rhetorics (overcoming and desire) as the foundation of the so called Religion of the Consumption. The first one is expressed by a particular IURD (Universal Kingdom of God Church, in English) conquer discourse, which is mainly materialized in goods belonging. This represents the edge point of someone's life, asserting the presence of God and assuring happiness. The

second one builds itself, discursively, as a process focused on its own moralization. It puts desire as a moral obligation. We aim to understand how nowadays religions are becoming more and more connected to modern consumption, taking in account the way mediatic testimonies are central to the promotion of a singular way of life. For this purpose, we analyze some testimonies from IURD believers

Keywords: Religion of consumption. Overcoming rethoric. Desire rethoric. Universal Church of the God Kingdom.

\footnotetext{
${ }^{1}$ Pós-doutora em Antropologia Social pela Universidade de Cambridge (UK). Doutora em Sociologia e mestre em Comunicação pela UFPE. Professora do PPGCOM da Universidade Federal de Pernambuco (UFPE), e do curso de Publicidade e Propaganda da UFPE. Brasil, Pernambuco, Recife. E-mail: k.patriota@gmail.com

${ }^{2}$ Mestre em Comunicação pela Universidade Federal de Pernambuco (UFPE), é especialista em comunicação pública pelo Instituto Federal de Pernambuco (IFPE) e bacharel em comunicação/jornalismo pela UFPE. Professora de Jornalismo da Unifavip - Devry. Brasil, Pernambuco, Recife. E-mail: carolinacfalcao@gmail.com ${ }^{3}$ Mestranda em Comunicação da Universidade Federal de Pernambuco (UFPE), graduada em Comunicação pela Universidade Federal de Alagoas (UFAL). Brasil, Pernambuco, Recife. E-mail: egbrodrigues@gmail.com
}

Comun. \& Inf., Goiânia, GO, v. 19, n. 01, p. 37-51, jan./jun. 2016 


\section{Resumen}

Este artículo empieza com la perspectiva del la creación de dos retóricas, de la "superación" y del "deseo", como base estructural de lo que clasificamos como la Religión del Consumo. La primera tiene expresión en el discurso de las conquistas de la IURD, materializado principalmente en la posesión de bienes materiales como la máxima representación de la felicidade y la prueba de la acción de Diós en la vida de los fieles. La segunda retórica, la del "deseo", se construye discursivamente en los procesos que visan su propio la moralización, casi convirtién dose en una "obligación moral". Nuestra propuesta es reflexionar como las religiones contemporaneas cada vez más se sintonizan al discurso del consumo moderno, para la promoción de una manera única de vivencia religiosa. Esas dos retóricas objetivan construir una fe racionalista, basada en una teología de los resultados, conocida como Teologia de la Prosperidad. Cuyos valores analisamos en los testigos de los fieles de la IURD en la red social digital Youtube.

Palabras clave: Religión del consumo. Retórica de la superación. Retórica del deseo. Iglesia Universal del Reino de Dios.

\section{INTRODUÇÃO}

laviane, Miriam, Conceição e Dona Geni possuem algo em comum: são
mulheres que passaram por privações materiais e conseguiram superar suas
dificuldades. No entanto, o que une a trajetória delas é muito mais do que testemunhos sobre persistência e vitória. As quatro personagens contam histórias que ilustram, de maneira muito apropriada, a vivência religiosa promovida pela Igreja Universal do Reino de Deus - IURD. São depoimentos que demonstram a efetividade de uma teologia que pretende ofertar 'resultados práticos' como um mecanismo válido para legitimar o conjunto de práticas e crenças promovidas pela referida igreja.

As crenças, por sua vez, possuem uma íntima relação com o que se convencionou chamar de 'fé', acastelando, inclusive, a ideia de que somos capazes de crer e/ou acreditar até naquilo que não conseguimos ver. A própria definição bíblica, contida no livro de Hebreus (11:1), diz que a fé é "a certeza de coisas que se esperam e a convicção de fatos que se não veem" e que esta fé, segundo a epístola do apóstolo Paulo aos Romanos (10:17), "vem pelo "ouvir".

Nesse sentido, aoobservarmosa promoção de uma "fé racional" (pedagogicamente ensinada pelo o que se pode "ver" ou "ouvir") na esfera discursiva da igreja que nos propomos a analisar, encontramos a emergência de duas retóricas em seus argumentos. A primeira retórica, nomeada aqui de "da superação", tem expressão no discurso de conquista da IURD, materializado principalmente na posse de bens materiais como a representação máxima da felicidade e prova da ação de Deus sobre a vida do fiel. A segunda, concebida como "do desejo", constrói-se discursivamente em processos que visam a sua própria moralização: a moralização

Comun. \& Inf., Goiânia, GO, v. 19, n. 01, p. 37-51, jan./jun. 2016 
do querer, do desejar intermitente, praticamente transformando-o numa "obrigação moral", que se volta para o consumo constante- o que une esta retórica com o que Campbell (2001) ponderou sobre o consumo moderno, principalmente na transcendência do seu fim em si mesmo e no seu sustento a partir de um característico sentido de "obrigação moral".

Assim sendo, ambas as retóricas encontram acolhida e justificação na Teologia da Prosperidade $-\mathrm{TP}^{4}$, que ao promover o consumo e moralizar o desejo, vem atualizar a relação entre religião e economia proposta por Weber (1996), mantendo a afinidade entre as duas esferas, mas deslocando o foco da relação religião/trabalho para a relação religião/consumo o que "mantém viva a religião, mas segundo uma lógica em que a Teologia da Prosperidade [...] é a ênfase" (MESQUITA, 2007, p. 132).

Com efeito, nas duas retóricas (da "superação" e do "desejo"), a promoção da credibilidade (exatamente como demandado pela retórica clássica), e da fé (que, segundo a Bíblia, "vem pelo ouvir"), resulta de ummovimento no qual um emissor vai se tornando crível a um receptor. De tal modo queentendemos ser preciso pensar o testemunho e sua validade pelo viés da credibilidade que ele pode conferir. Como explica Lipton (1998), o saber se configura a partir da fala (escrita ou oral) de outrem. Por isso, o testemunho se encontra na base do conhecimento humano sobre quase tudo. Dessa forma, o que se constrói como conhecimento importa tanto quanto o modo como algo se converte em testemunho. Essa conversão se dá através da justificação.

Se o testemunho é uma peça central no conhecimento humano, a justificação é o que valida o testemunho para que se possa acreditar nele. Um testemunho justificado, ou confiável, atende a duas condições, segundo o autor. A primeira é da ordem da honestidade de quem testemunha. A segunda, da competência de quem testemunha. Honestidade e competência são, portanto, a base legitimadora e crível do testemunho. Como são, justamente, os testemunhos que suscitam as duas retóricas das quais fizemos referência, se constituindo como a concretude da legitimação da Igreja Universal e da sua teologia de resultados, nos propomos a analisa-los aqui.

\footnotetext{
${ }^{4}$ Tal teologia, grosso modo, se fundamenta na legitimidade do fiel usufruir de uma vida abundante e próspera (em todos os sentidos que a prosperidade possa ser percebida: nos recursos materiais, na saúde do corpo, na vida familiar, amorosa e profissional). Rodrigues (2003) vai além e enfatiza que o tema da prosperidade ainda transcende as questões meramente espirituais, psicológicas e simbólicas da existência humana. Para o autor, a ideia da posse, (alicerce dessa corrente teológica) quando ligada aos ideais da prosperidade, proclama não apenas uma projeção psicológica, imaginária, imbricada na magia do sonho de consumo (RODRIGUES, 2003, p.24), mas está intensamente ligada com as questões concretas no domínio material, com o usufruto real de bens, não só simbólicos mas também palpáveis, corporificados e produzidos na sociedade capitalista contemporânea (apud PATRIOTA, 2008, p.115). A TP é a base teológica e doutrinária da Igreja Universal do Reino de Deus.
}

Comun. \& Inf., Goiânia, GO, v. 19, n. 01, p. 37-51, jan./jun. 2016 
Este artigo, por conseguinte, parte da perspectiva de instauração da "Retórica da superação" e da "Retórica do desejo" como fundamentos estruturais do que chamamos de Religião do Consumo (BRONSZTEIN, 2014): um formato de religiosidade que se estrutura e cresce na medida em que estimula, promove e celebra, através de testemunhos, o consumo como resposta ao ideal de felicidade proveniente de uma boa relação com Deus.

Como pontos de partida temos dois pilares: a profícua relação das formas religiosas contemporâneas (principalmente as ofertadas na mídia) com o consumo modernoe a total dependência dos testemunhos dos fiéis para a promoção de um modo singular de vivência religiosa. Tais pilares, portanto, estão em congruência com o panorama religioso moderno, caracterizado "por um movimento irresistível de individualização e de subjetivação das crenças e das práticas" (HERVIÉU-LÈGER, 2008, p.139). Assim sendo e com o intuito de conferir materialidade à nossa proposta, refletiremos neste artigo a partir dos testemunhos de Flaviane ${ }^{5}$, Miriam $^{6}$, Conceição ${ }^{7}$ e Dona Geni ${ }^{8}$, todos eles coletados da "Nação dos 318 "9 e disponíveis na plataforma do YouTube.

\section{ECOS DE UMA FÉ RACIONAL: A RETÓRICA DA SUPERAÇÃO}

Antes de nos determos sobre o que dizem essas mulheres, é importante ressaltar uma fala proferida pelo líder máximo da IURD, o Bispo Edir Macedo ${ }^{10}$, num vídeo disponibilizado no YouTube, em abril de 2011. O vídeo, intitulado "O segredo do sucesso", reproduz uma palestra do bispo durante evento da Associação das Mulheres Cristãs no qual, Macedo relembra sua visita à equipe de jornalismo logo após a compra da TV Record.

Havia aquela dúvida, aquela polêmica... porque a Record estava falida, irremediavelmente falida. E então, nós conversamos, procuramos lá... passar fé para as pessoas, para os funcionários e especialmente para aquele pessoal

\footnotetext{
${ }^{5}$ Disponível em: <https://www.youtube.com/watch?v=NzwYFXJ0G3>. Acesso em: 26 jan. 2015.

${ }^{6}$ Disponível em: $<$ https://www.youtube.com/watch?v=Lq0cpfWBJKs>. Acesso em: 26 jan. 2015.

${ }^{7}$ Disponível em: <https://www.youtube.com/watch?v=XYvw70Q5EOg>. Acesso em: 26 jan. 2015.

${ }^{8}$ Disponível em: https://www.youtube.com/watch?v=sssKNINwohI. Acesso em: 26 jan. 2015.

${ }^{9}$ Reunião semanal da IURD também conhecida como A Corrente dos Empresários. Segundo a denominação, Nação dos 318 Pastores (baseado em Gênesis 14:14) é um ministério que trata a vida financeira e profissional dos fiéis. De acordo com o site da igreja, "a reunião recebe pessoas de diversos níveis culturais. São profissionais autônomos, empresários, pessoas que anseiam voltar ao mercado de trabalho ou abrir seu próprio negócio e os que querem crescer profissionalmente. Muitos são os testemunhos de quem conseguiu sucesso participando do encontro". Todos os testemunhos analisados no artigo foram dessa reunião, que ocorre todas às segundas-feiras em todos os templos da Igreja Universal. Os testemunhos aqui analisados também foram veiculados na televisão aberta.

${ }^{10}$ Desde sua fundação, em 1977, a trajetória da Igreja Universal segue o mesmo rumo que a de Edir Macedo, bispo primaz e seu fundador, assim como suas características, herdadas dele. De um simples funcionário de uma loteria no Rio de Janeiro, filho de pais humildes e vida modesta, Macedo se tornou um dos maiores e mais ricos líderes religiosos do mundo, demonstrando seu forte espírito empreendedor e centralizador (FERRARI, 2007).
}

Comun. \& Inf., Goiânia, GO, v. 19, n. 01, p. 37-51, jan./jun. 2016 
[equipe de jornalismo]. E aí os jornalistas... assim... muitos com ar de deboche, de... incredulidade, de... eles perguntavam 'ah, como é que você tem certeza que o governo vai lhe dar a concessão?' E eu falei: 'Ó, presta atenção, rapaz. Só não vou receber essa concessão se passarem por cima do cadáver de Deus'. Essa foi a minha resposta. Então houve uma determinação, uma crença, eu acreditava. Se ninguém acreditava, não importa. Eu acreditei... e a Record taí ${ }^{11}$ [sic] (MACEDO, 2011).

Há marcadores, nesse trecho da fala de Edir Macedo, muito eloquentes e fecundos que merecem ser considerados. O primeiro deles diz respeito a uma ideia de instabilidade e descrença, o segundo aponta para a maneira de superara situação e o terceiro revela (ou confirma) tal superação. Com a emissora "irremediavelmente falida" e uma equipe de jornalistas incrédulos, o religioso mostrou que a situação poderia ser revertida mediante a adoção de duas atitudes: determinação e fé. A superação da crise fica evidente em sua fala. As situações se equivalem entre estar "irremediavelmente falida", a "incredulidade" e o "deboche" da equipe de jornalistas. Soma-se a isso como a determinação e a crença transformaram a situação: "a Record taí".

Não é à toa que utilizamos a fala de Edir Macedo para "calçar" este trabalho. É que a figura do religioso e da igreja fundada por ele se confundem e desdobram-se uma na outra, de tal modo que a própria história de superação pessoal do bispo vai se construindo como um dispositivo de autovalidação do crer, expressão que Herviéu-Lèger (2008) usa para determinar as práticas mais comuns entre os crentes contemporâneos. Essa autovalidação está fundada em três eixos: o testemunho pessoal, a troca de experiências individuais e a execução de ações de aprofundamento coletivo.

É aí que entram em cena os testemunhos da Nação dos 318, dos quais selecionamos aleatoriamente as histórias de Flaviane, Miriam, Conceição e Dona Geni, disponibilizados no YouTube. Elas performatizam uma conquista (a fase final na busca pela felicidade) associada à noção de posse, materializada em listas de bens de consumo que lhes confere distinção em meio aos outros fiéis. O poder de compra está estritamente relacionado à realização pessoal - e esta ao individualismo religioso moderno, centrado no sujeito e em seus desejos (CAMPBELL, 2001). Há, portanto, duas grandes retóricas atuando na autovalidação: a da superação e a do desejo. Ambas orientadas pela premissa básica da Religião do Consumo (BRONSZTEIN, 2014), tendo o consumo (estimulado e promovido) como a expressão máxima da boa relação com Deus.

\footnotetext{
${ }^{11}$ Disponível em: <https://www.youtube.com/watch?v=hCcbQTFLJB8>. Acesso em: 26 jan. 2015.
}

Comun. \& Inf., Goiânia, GO, v. 19, n. 01, p. 37-51, jan./jun. 2016 


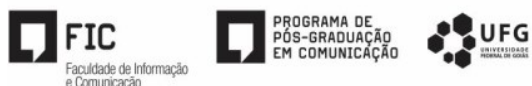

Nessa perspectiva, a noção de posse equivale à salvação. "Possuir" é um sinal de prosperidade, do "derramamento das bênçãos divinas" sobre aquele que crê e pratica a fé inteligente ou racional. "O enriquecimento demarca a relação de fidelidade do converso para com o Sagrado, confirma que o Senhor está abençoando-o" (RODRIGUES, 2003, p.92) e a posse respalda e materializa a benção. Para tanto, testemunhar é uma condição indispensável para garantir esse progresso. Primeiro porque demarca uma distinção entre aqueles que “venceram" e os demais fiéis e, segundo, porque colocar a 'fé em ação', ao contar sua história de superação - destacando o momento da conversão, da mudança de rumo -, é uma obrigação de todo fiel que tem sua vida restaurada 'por intermédio' do Espírito Santo e mediação da igreja.

Analisando a história da IURD, Gomes (2011) mostra que o "circuito da conquista" é uma estrutura arquetípica de quatro fases (perseguições, revolta, sacrifício e conquista) que confere legitimidade e autenticidade aos discursos da igreja. No "circuito da conquista" dos vencedores da IURD vemos como a retórica da superação se pauta em uma história de privação que, após a conversão e a realização de uma "fé racional", resultou em uma "vida de abundância", substanciada no consumo lícito e sem constrangimentos de tudo aquilo que representa para o fiel a prosperidade materializada.

Com essa chave, o consumo alicerça a ideia de felicidade transmitida pela igreja, servindo como medidor de seus graus (ser mais ou menos feliz vai depender, principalmente, do capital econômico do fiel). Uma característica marcante da identidade institucional da IURD é, por esse motivo, a importância dada ao dinheiro em suas práticas e discurso, este concebido como o intermediário entre a bênção e seu provedor: Deus (GOMES, 2011).

Por outro lado, na retórica da superação da igreja, as perseguições sofridas por ela durante sua trajetória devem ser resgatadas e enfatizadas a todo o momento nos testemunhos. Logo, da mesma forma que a IURD e seu líder, o bispo Macedo, superaram as crises, os fiéis, por meio da confissão positiva e do sacrifício financeiro, também alcançarão o sucesso. Para tanto, como prega a instituição, é preciso que o crente esteja em constante "estado de revolta", diferentemente da contemplação, exigindo de Deus tudo o que é merecido e colocando sua féem ação: só assim se podem ver os resultados.

Quando Conceição relembra o momento em que entrou na IURD, seu testemunho é contundente: "Cheguei fracassada [...] vinha de geração em geração de uma família de pobreza". Seu relato mostra uma vida sem qualquer conforto material: morava numa casa de pau, tinha apenas uma roupa de saco de linha, não possuía sapatos e mal se alimentava, pois a praga tomava conta da plantação e da criação da família no interior de Goiás. Ao chegar à

Comun. \& Inf., Goiânia, GO, v. 19, n. 01, p. 37-51, jan./jun. 2016 
cidade grande, sua sorte não mudou, casou com um pequeno comerciante cuja loja estava cheia de dívidas e passou a ser acometida pelas maisvariadas enfermidades:

Com tudo isso, com a vida que eu tinha, desde a infância, de miséria, começou a aparecer enfermidades... começou a aparecer depressão, é... vultos, hérnia no estômago, até isso tinha... gastrite, artrose nas juntas, que até então eu era até nova, mas apareceu todas essas enfermidades... [sic].

Há um encadeamento lógico entre a vida de privações e o grau de sofrimento que Conceição apresenta que validam o nível de honestidade do testemunho dela. O mesmo encadeamento apresentado por Dona Geni, uma mulher que ficou viúva após um casamento de 14 anos e 9 meses de "vida boa". Após a morte instantânea do marido num acidente de carro, ela chegou ao "fundo do poço". A empresa estava falida, ela teve depressão e acumulava dívidas que totalizam R\$200 mil:

O pior momento foi quando não tinha mais condição de pagar os funcionários e tive que dividir um pacote de arroz com os funcionários. Não tinha nada pros meus filhos e não tinha condição de quitar as dívidas, nem pagar o salário dos funcionários. [sic]

É interessante notarcomo a incapacidade de consumir das duas fiéis-testemunhas, geradas pela situação de falência e endividamento, vão se construindo em paralelo com a noção de doença. Se no exemplo utilizado com Macedo, a falência da TV Record estava associada a uma situação de descrença, no caso das duas mulheres citadas, há uma clara relação com a fragilidade do corpo, expressa na doença. Não consumir, ou não o fazer de maneira competente, nos parece o tipo de acontecimento que acomete pessoas com certa fraqueza moral. Podemos argumentar que existe uma conexão semântica que circula em torno da falência que inicia os testemunhos na IURD: ela é financeira (incapacidade de pagar as próprias contas ou de ter coisas); é moral (expressa na descrença e na apatia) e é também física, uma vez que se manifesta no corpo através da enfermidade.

Se no eixo da honestidade é preciso demonstrar uma falência compatível com a privação ou com as perseguições a que se foi exposto, no eixo da competência, a testemunha deve evidenciar habilidade em reproduzir retoricamente as diretrizes da IURD no caminho do circuito da conquista. A retórica da superação assume um tom pedagógico no que se refere à forma de vencer a falência. A competência do testemunho iurdiano está na assimilação das "palavras dos homens de Deus"12, proferidas nas reuniões da Nação dos 318, mas também na capacidade de voltar a consumir, indicando uma vida próspera e digna e desencadeando a

\footnotetext{
${ }^{12}$ Numa clara menção aos (318) pastores da IURD, mas também aos fiéis que após a conversão e ingresso na igreja passaram a ser, igualmente, homens e mulheres de Deus.
}

Comun. \& Inf., Goiânia, GO, v. 19, n. 01, p. 37-51, jan./jun. 2016 
segunda retórica: a do "desejo": o querer cada vez mais e cada vez 'do melhor' que está destinado aos filhos de Deus - tudo isso sem constrangimentos, de forma lícita, aceitável e com vistas à obtenção de uma vida repleta dos signos terrenos de sucesso como resposta ao ideal de felicidade.

Temos, nesse caso, o exemplo de Miriam, esposa de um médico, que tinha "do bom e do melhor", com uma vida de luxo, conforto e sem preocupações. Após perderem tudo, o casal se vê falido, humilhado e perdido em dívidas. Até que encontram uma pessoa que mostra o caminho que pode mudar suas vidas, a IURD. "Quando cheguei à igreja, fui muito bem recebida, muito bem atendida. Muito bem instruída e comecei a fazer tudo o que me ensinavam”. Os resultados apareceram: “O meu marido começou a prosperar. Ele conseguiu comprar uma clínica à vista, entendeu? Reformar... e esse foi o começo do nosso sucesso".

O mesmo tom pedagógico de assimilação pode ser encontrado no testemunho de Flaviane, dona de uma boutique multimarcas em Goiânia. Ela conta que tinha uma vida boa, marcada por carros importados e viagens internacionais, até o marido perder o emprego na multinacional na qual trabalhava. A situação de crise a levou até a Nação dos 318 , onde recebeu as instruções de que precisava para abrir seu próprio negócio, uma loja de roupas femininas. "Participo da Nação e participando... lutando, vieram as direções e as conquistas estão aí".

A competência revelada, e que em parte valida o testemunho, se expressa na participação nas reuniões da Nação, na compreensão e na aceitação das direções que são dadas lá. Trata-se da expressão de uma vivência religiosa nos moldes do que Macedo já professava (determinação e crença) no vídeo mencionado inicialmente. Tanto Miriam quanto Flaviane endossam essa receita de sucessoe testemunham acerca do circuito da conquista. A primeira, ao finalizar seu testemunho, compartilha a lição. "Eu só tenho de dizer uma coisa: não desanime, persevere. Porque a vitória é certa. Mas a vitória só vem com a presença de Deus, você sendo perseverante, lutando e contando com Ele".

Quando perguntada sobre os conselhos que daria para alguém que se encontra na mesma situação em que ela estava, Flaviane resume: "[Aconselho] a participar da Nação, a seguir o conselho do homem de Deus e agir a fé, né? A gente acredita em Deus, a gente tem que ter a certeza de que Deus pode fazer tudo. É igual uma criança, ela confia no pai, na mãe e nós temos que confiar em Deus".

O outro aspecto da competência do testemunho está no repertório de consumo que é apresentado. Não se trata de qualquer consumo. É um consumo qualificado, redentor, que tira a testemunha da situação de crise e falência e demonstra a habilidade adquirida quando se

Comun. \& Inf., Goiânia, GO, v. 19, n. 01, p. 37-51, jan./jun. 2016 
passou a seguir as direções propostas na Nação. Se na fala de Macedo, a simples menção à rede de tevê que ele detém ("a Record taí") é suficiente para ilustrar sua competência, os testemunhos precisam de um repertório mais amplo, que ampare material e simbolicamente o circuito da conquista.

Voltemos à Conceição que, ao superar a fase de sofrimento e falência, enumera suas conquistas:

Hoje, àquela época com uma loja, hoje eu tô com 32 lojas em vários estados. Todas com... limpinha, não tem nenhum protesto, não tem nada. Hoje eu tô assim. Pago todos os meus compromissos, eu tenho o melhor apartamento, eu tenho o melhor... a melhor mobília, né? Que eu posso escolher o local que eu queira comprar, eu compro. Posso escolher, né? Escolher o melhor carro. Eu tenho do bom e do melhor. [sic]

A lista também é extensa e confere distinção para Geni, que relata seu sucesso:

Hoje somos prósperos. Temos duas empresas, temos vários imóveis, temos uma vida próspera, regalada, não nos falta nada. Estamos muito bem, graças a Deus. [...] Agora nossa última aquisição foi uma fazenda, no valor de um milhão e setecentos mil reais, dois apartamentos, temos imóveis... vários imóveis. [sic]

A marca das conquistas testemunhadas se estabelece a partir da capacidade de consumo revelada. Justamente por sua ocorrência nesse âmbito, a atuação divina dentro da lógica iurdiana é também aspiracional. Além de reconhecer o vasto patrimônio adquirido, o fiel não deixa de continuar a desejar, uma vez que desejo, crença e determinação caminham juntos e se produzem mutuamente na tradução desses testemunhos de superação, suscitando a segunda retórica, a do "desejo" e formando, assim, uma espiral em contínuo movimento entre superação e desejo: as histórias de superação incitam o desejo (de ter, de consumir) e o desejo desperta a determinação para (se) superar.Como bem ilustrou Flavianeao ressaltar a principal lição aprendida nas reuniões da Nação dos 318: "Vou levar isso em todos os sentidos da minha vida: usar a fé cada dia mais". Tal qual uma linha de crédito de recursos ilimitados, a fé (acionável, inteligente e racional) que anima os crentes da IURD - que embarcam nesse espiral de superação e desejo - é capaz demobilizar para a aquisição de tudo: da tranquilidade espiritual ao patrimônio que demonstra a atualização ${ }^{13}$ das bem-aventuranças.

Dessa forma, a figura do testemunhante vencedor - que se "converteu"14 - se reveste de um caráter exemplar (HERVIÉU-LÈGER, 2008), pois só o indivíduo que se converte num

\footnotetext{
${ }^{13}$ Chamamos aqui de "atualização" porque as bem-aventuranças como descritas nos Evangelhos de Mateus e de Lucas, serviriam para revelar aos homens a verdadeira felicidade, e esta não estava atrelada a bens materiais - ao contrário - Jesus ensinou que bem aventurados seriam os que tinham o foco no amor e na humildade.

${ }^{14}$ Convertido no sentido da "metanoia", da mudança de mente, de rumo, com um novo modo de viver - visto que não são necessários o batismo ou a adesão como membro da IURD para poder testemunhar.
}

Comun. \& Inf., Goiânia, GO, v. 19, n. 01, p. 37-51, jan./jun. 2016 


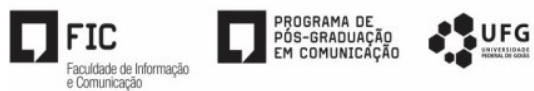

novo modo de vida e vive segundo as suas regras possui a capacidade "racional" - de conquistar aquilo que, como filho de Deus, lhe pertence. Nesse sentido, é ao fiel da IURD que está reservada uma vida próspera e feliz, na qual as crises devem sempre ter um lugar de destaque nos testemunhos e servir de exemplo de superação para todos àqueles que buscam o mesmo para as suas vidas.

\section{ECOS DOS SONHOS: A RETÓRICA DO DESEJO}

Como pontuamos anteriormente, é com os testemunhos de superação que a IURD deflagra o desejo, ampliando o "querer" entre seus frequentadores. É aqui que os discursos de superação(circulantes na Universal e nas plataformas midiáticas utilizadas por ela) sãocorporificados nos testemunhos de seus fiéis e se nutrem para estimular e moralizar o desejo entre os que assistem.

A retórica do desejo, consequentemente, é instaurada nos mesmos moldes em que se sustentam as noções clássicas do entendimento retórico. Suas funções persuasiva e pedagógicaabrangem, igualmente, aspectos argumentativos e oratórios, e mesmo que se fundamentem em meios mais ligados à razão (no raciocínio silogístico - presente na fé racional que a IURD propõe - e nos baseados nos exemplos dos que testemunham na IURD), também se estruturam nos elementos mais voltados à afetividade: no ethos, "caráter que o orador deve assumir para chamar a atenção e angariar a confiança do público" (REBOUL, 2004, p. 17) e no pathos, "as tendências, os desejos, as emoções do auditório das quais o orador poderá tirar partido" (Idem).

Com efeito, é nesse lócus que contemplamos o "sonhar acordado"(CAMPBELL, 2001) ganhar força pela retórica do desejo instaurada nos ideais de consumo dos fiéis que aderem a IURD e às suas promessas de abundância material. Desejos imaginados por estes fiéis e responsáveis por leva-los à igreja, são ativados durante os testemunhos assistidos, graças à identificação que as falas dos testemunhantes geram nos ouvintes: ethos e pathos em perfeita ação. Todos chegaram da mesma forma (sofrendo), todos estão tendo a mesma atitude (adesão à IURD e busca pela intervenção divina por meio das trocas financeiras) e todos sonham com a aquisição de bens que transformem suas realidades (BRONSZTEIN, 2014, p.138).

Essa elaboração imaginativa surgida a partir dos desejos de consumo dos fiéis é igualmente apresentada nos discursos dos testemunhantes, quando estes relatam que também ouviram um testemunho e desejaram o mesmo para as suas vidas. Na retórica do desejo da 
'Religião do Consumo' o exemplo é didático e altamente necessário para desencadear o sonho acordado e, só com ele, é possível mobilizar os fiéis para a atitude de entrega financeira à igreja.

O "sonhar acordado", por conseguinte, abarca a busca "pelo prazer dentro do processo normal da expectativa imaginativa ou a especulação sobre o futuro" (CALVELLI, 2009, p.57) que as pessoas costumam ter frente aos desafios e lutas da vida; como no depoimento de Geni, ao lembrar-se de quando seu marido faleceu e sua situação financeira se degenerou: "com o falecimento dele eu perdi o controle de tudo, não tinha mais motivação". De fato, ao depararse com a falta de perspectivas, o estado de revolta aflora e o sonho acordado é devidamente requerido em seguida: ele pavimenta o caminho para a mudança de vida do fiel, ao ganhar uma nova perspectiva "pela escuta das atraentes e abundantes listas de bens que os que aderem à Religião do Consumo conseguem obter" (BRONSZTEIN, 2014, p.138-139).

Como a persuasão é feita a partir dos testemunhos, é razoável ponderar que estes não são acontecimentos isolados: eles se complementam se somam e corroboram com testemunhos outros, que lhes antecedem e sucedem. Flaviane, Miriam, Conceição e Dona Geni, logo, não são solitárias na IURD. Expressamideais e sonhos que parecem ser de todos os que estão na Nação: elas testemunham em acordo e no mesmo tom devários outros testemunhos. A capacidade persuasória delas, mesmo que intuitiva e espontânea,está sobremodo relacionada à capacidade de compreender e identificar a quem se está falando, promovendo a força retórica de um mesmo desejo, em testemunhos que se interpelam e buscam defender sua causa de forma persuasiva.

Soma-se a isso o fato de que "desejar" não é só uma atitude moralmente aceita e estimulada no discurso dosfiéis que testemunham nos templos e na mídia e dospastores da igreja, é também uma ação "ensinada" - o que está evidente nas falas aqui analisadas. No testemunho de Conceição, por exemplo: “Ao chegar na Nação dos 318, eu percebi que eu estava no caminho errado, eu não vencia porque eu não tinha o esclarecimento de Deus. Era daquela maneira que era correta: os homens de Deus esclarecendo em cima da palavra de Deus" [sic].

Há, portanto, uma "pedagogia do consumo", que "ensina", a partir daquilo que se convencionou chamar de "fé inteligente", o que consumir ecomoconsumir. Tão somente porque é através do consumo que os fiéis se identificam com estilos de vida de estratos sociais mais favorecidos e, consequentemente, constroem para si uma identidade desejável e de essênciadesejante. Listar, orgulhosamente, todos os bens materiais adquiridos após a adesão voluntária à IURD confere um sentido existencial à atividade de consumir e continuar a querer, umaprática de autoreconhecimento possível aosque estão dispostos a colocar a "fé em ação" e

Comun. \& Inf., Goiânia, GO, v. 19, n. 01, p. 37-51, jan./jun. 2016 
contribuir com a obra da igreja - que se reverte, potencialmente, em melhoria da sua própria vida.

Por conseguinte, não é por acaso que, ao se acomodar a uma sociedade de consumo que faz dos bens materiais os medidores da felicidade de cada indivíduo -, a Teologia da Prosperidade, quando materializada nas falas dos fiéis, moraliza o desejo e reposiciona o seu lugar discursivamente, fazendo-o parte de um "estado de revolta" permanente e altamente positivo, exatamente como são os parâmetros da "confissão positiva". Desejar é a condição primeira para se "revoltar"; é o contrário de aceitar, de contemplar, de não "agir na fé".

É o caso de Flaviane, que ao relatar o momento em que marido perdeu tudo, relembra o turning point de sua história: "Foi aí que nós nos revoltamos e decidimos ser cabeça e não cauda"15. É neste estágio de revolta que o casal conhece a Nação dos 318 e a história passa a assumir um tom positivo.

Para o hedonista moderno, assim como para os fiéis da Igreja Universal, o prazer é a qualidade de uma experiência imaginativa daquele que, ao assistir aos testemunhos de superação, determina a conquista de todos os bens que são seus por "herança"16 (devaneio que gera prazer), acreditando fortemente na concretização daquilo que se delineia na sua imaginação (o "sonhar acordado", como proposto por Campbell em sua Ética Romântica). Os significados são então manipulados de modo que o indivíduo exerça total controle sobre os estímulos que experimenta na imaginação, ressignificando o desejo como uma atitude moralmente aceitável e obrigatória para aqueles que se consideram verdadeiros "filhos de Deus". Assim, como nos anúncios publicitários, a retórica do desejo nos testemunhos iurdianos "se dirige mais aos sonhos do que às necessidades, numa tentativa de associar determinados produtos a acalentadas ilusões e, consequentemente, despertar [ainda mais] o desejo" (CAMPBELL, 2001, p.133).

Esse desejo, vale ressaltar, se estabelece não só na confiança que a testemunha tem de que nada faltará às suas necessidades, como também na certeza de que as benesses materiais enviadas por Deus são infinitas, inesgotáveis e, inclusive, estão além do que se pode esperar. Como materializado no testemunho de Miriam, que ao enumerar suas conquistas, cita a

\footnotetext{
${ }^{15}$ Com referência ao texto bíblico de Deuteronômio 28:13, que indica uma condição e um resultado para a antiga situação de sofrimento: "E o Senhor te porá por cabeça, e não por cauda; e só estarás em cima, e não debaixo, se obedeceres aos mandamentos do Senhor teu Deus, que hoje te ordeno, para os guardar e cumprir".

${ }^{16}$ Como no texto de Levítico 20:24, que Deus promete entregar a herança dos seus filhos: [ ]...eu a darei a vocês como herança, terra onde há leite e mel com fartura. Eu sou o Senhor, o Deus de vocês, que os separou dentre os povos.
}

Comun. \& Inf., Goiânia, GO, v. 19, n. 01, p. 37-51, jan./jun. 2016 
口

aquisição de uma chácara como algo não planejado. "Compramos uma chácara, coisa que também nunca passou pela nossa cabeça porque Deus nos surpreende, entendeu?”.

Arriscamos-nos a ponderar que o desejo, então, não está sempre configurado como algo específico; não necessariamente se quer algo definido a priori. O desejo se expressa como um potencial, como algo a que qualquer pessoa poderia aderir e, tão logo a adesão se confirme, a aspiração deixa de ser meramente desejosa e passa a reassumir os contornoscíclicos da superação.

\section{CONSIDERAÇÕES FINAIS}

Superação e desejo andam de mãos dadas nos testemunhos midiáticos da IURD e cumprem uma função pedagógica específica: ensinam um tipo de crença que, pela racionalidade e visibilidade que suscitam, vai além das questões metafísicas, se materializando numa competência consumidora. Nessa perspectiva, mais do que "convencer" ou atestar sobre uma teologia de resultados (como se constitui a TP), os testemunhos iurdianos ecoam no sentido de instaurar a moralização de todas as vontades de consumo dos seus fiéis, levando-osao "sonhar acordado" do consumismo moderno, como a "ponta" da espiral de superação e desejo, da qual nos referimos.

Se as histórias de superação (uma das principais estratégias da IURD para cooptar novos fiéis através das plataformas midiáticas), por si só são capazes de mobilizar a atenção e a empatia de pessoas que também estão passando por situações difíceis similares (endividamento, perda da qualidade de vida, perda de crédito e a incapacidade de consumir), a retórica do desejo incita e habilita a adesão final. Contudo, diferente dos testemunhais que nos habituamos a assistir na publicidade, que estimulam o desejo consumista pelos produtos anunciados e endossados por consumidores outros, é imperativo ressaltar que os testemunhos da Religião do Consumo só se tornam eficientes quando o desejo também se traveste de superação.

Logo, as ordens semânticas da conquista (comprei, lucrei, conquistei, assumi etc) apontam para essa elaboração: enquanto a superação está devidamente demarcada (situação de crise - adesão à fé racional da Religião do Consumo - conquistas), o desejo se mostra como um amplo espaço para manifestação da eficiênciade uma fé que, além de ser o dínamo que viabiliza o acesso ao que quer que se deseje, igualmente se pretende "inteligente".

Essa relação, a nosso ver, só pode ser entendida através do testemunho e dos seus eixos da verdade e da competência para se efetivar. No caso da IURD, vimos como o âmbito da

Comun. \& Inf., Goiânia, GO, v. 19, n. 01, p. 37-51, jan./jun. 2016 
verdade se ampara no repertório consumidor do crente: marcas de roupa, imóveis e seus valores de mercado, o nome limpo na praça etc. No que diz respeito à competência testemunhal, há o atendimento às diretrizes professadas pelos homens de Deus (seguir tudo corretamente, fazer tudo certo etc). O desejo, nesses casos, não diz respeito apenas a algo material específico, já que também encerra a vontade de direção que vai guiar o crente pelo caminho da superação. Como na quadrangulação da fórmula da fé que Kenneth Hagin (Texas, EUA, 1918), a quem se atribui a sistematização da TP, afirmou ter recebido diretamente de Jesus: 1- "Diga a coisa" Positiva ou negativamente, tudo depende do indivíduo. "De acordo com o que o indivíduo quiser, ele receberá" (HAGIN, 1983); 2- "Faça a coisa" Seus atos irão derrotá-lo ou lhe darão vitória. "De acordo com sua ação, você será impedido ou receberá" (HAGIN, 1983); 3- "Receba a coisa" Compete a nós a conexão com o dínamo do céu. "A fé é o pino da tomada, basta conectá-lo". (HAGIN, 1983) e 4- "Comente a coisa" A fim de que outros também possam crer. (HAGIN, 1983).

Destarte, a TP da Religião do Consumo encontra guarida na ligação entre as duas retóricas que animam o testemunho iurdiano, mas ela vai além: se movimenta pelo desejo de direção que leva à superação. Uma fé racional e, nomeadamente, "inteligente", não poderia operar por outra lógica numa teologia que busca evidenciar "resultados". Afinal de contas, as duas retóricas só se unem em espiral pela necessidade pedagógica do fiel de não só testemunhar (demonstrando a sua adesão livre, espontânea, vitoriosa e, portanto, racional), mas igualmente pelo imperativo de desejar, por meio dessa fé em ação,a manifestação material (discursivamente moralizada e, por conseguinte, lícita) da bênção divina em sua vida: com consumo, muito consumo

\section{REFERÊNCIAS}

ALMEIDA, J. F.de. Trad. A Bíblia Sagrada. 2. ed. rev. e atual no Brasil. São Paulo: Sociedade Bíblica Brasileira, 1993.

BÍBLIA, N. T. Hebreus. Português. Bíblia Sagrada. Traduzida por João Ferreira de Almeida. São Paulo: King's Cross Publicções, 2007. cap. 11, vers. 1.

BÍBLIA, N. T. Paulo aos Romanos. Português. Bíblia Sagrada. Traduzida por João Ferreira de Almeida. São Paulo: King’s Cross Publicções, 2007. cap. 10, vers.17.

BÍBLIA, A. T. Deuteronômio. Português. Bíblia Sagrada. Traduzida por João Ferreira de Almeida. São Paulo: King’s Cross Publicções, 2007. cap. 28, vers. 13.

Comun. \& Inf., Goiânia, GO, v. 19, n. 01, p. 37-51, jan./jun. 2016 
BÍBLIA, A. T. Levítico. Português. Bíblia Sagrada. Traduzida por João Ferreira de Almeida. São Paulo: King's Cross Publicções, 2007. cap. 20, vers. 24.

BRONSZTEIN, K. P. Nação dos 318: a religião do consumo na igreja universal do reino de Deus. Revista Comunicação, Mídia e Consumo, São Paulo, ano 11, vol. 11, n. 30, p. 125-142, jan./abr. 2014.

CALVELLI, H. O fenômeno da 'benzeção moderna' à luz da teoria do consumo moderno. Interações - Cultura e Comunidade, Uberlândia, v. 4, n. 5, p. 49-64, 2009.

CAMPBELL, C. A ética romântica e o espírito do consumismo moderno. Rio de Janeiro: Rocco, 2001.

FERRARI, O. A. bispo S/A: A Igreja Universal do Reino de Deus e o exercício do poder. 3. ed. São Paulo: Ave-Maria, 2007.

GOMES, E. C. A era das catedrais: a autenticidade em exibição. Rio de Janeiro: Garamond, 2011.

HAGIN, K. Compreendendo a unção. Trad. Gordon Chown. Rio de Janeiro: Graça Editorial, 1983.

HERVIEU-LÉGER, D. O peregrino e o convertido: a religião em movimento. Petrópolis: Vozes, 2008.

LIPTON, Peter. The Epistemology of Testimony. Studies in History Philosophy and Science Journal, London, v. 29, n. 1, p. 1-31, 1998. Disponível

em: $<$ http://www.hps.cam.ac.uk/people/lipton/epistemology_of_testimony.pdf $>$. Acesso em: $27 \mathrm{jan}$. 2015.

MESQUITA, W. Um pé no reino e outro no mundo: consumo e lazer entre pentecostais. Horizontes Antropológicos, Porto Alegre, v. 13, n. 28, p. 117-144, 2007.

PATRIOTA, Karla. O show da fé: A religião na sociedade do espetáculo. Tese de Doutorado em Sociologia do Programa de Pós-graduação em Sociologia da Universidade Federal de Pernambuco UFPE, Recife, 2008.

REBOUL, O. Introdução à retórica. São Paulo: Martins Fontes, 2004.

RODRIGUES, K. F. Teologia da prosperidade, sagrado e mercado: um estudo sobre a Igreja Universal do Reino de Deus em Caruaru-PE. São Paulo: Edições ABHR: Edições FAFICA, 2003.

SERRA, P. O princípio da credibilidade na seleção da informação mediática. Revista Interamericana da Comunicação Midiática, Santa Maria, n. 1, 2003.

WEBER, Max. A ética protestante e o espírito do capitalismo. São Paulo: Pioneira, 1996.

NAÇÃO dos 318 Rn: o segredo do sucesso. Produção de Bispo Macedo. São Paulo: 2011. Disponível em: $<$ https://www.youtube.com/watch?v=hCcbQTFLJB8>. Acesso em: 26 jan. 2015.

Recebido em: 29/06/2015

Aceito em: 12/10/2015

Publicado em: 11/10/2016

Comun. \& Inf., Goiânia, GO, v. 19, n. 01, p. 37-51, jan./jun. 2016 